\title{
PENYELESAIAN DAN UPAYA MENEKAN JUMLAH PEMBIAYAAN BERMASALAH (NON PERFORMING FINANCING/NPF) PADA BANK SYARIAH MANDIRI KANTOR CABANG KUDUS
}

\author{
Alfi Maghfiroh, Suparnyo dan Dwiyana Achmad H. \\ Email : alfimaa11@gmail.com, suparnyo@umk.ac.id,dwiyana.achmad@umk.ac.id \\ Fakultas Hukum Universitas Muria Kudus
}

\begin{abstract}
ABSTRAK
Penelitian yang berjudul "Penyelesaian dan Upaya Menekan Jumlah Pembiayaan Bermasalah (Non Performing Financing/NPF) pada Bank Syariah Mandiri Kantor Cabang Kudus" ini bertujuan untuk mengetahui faktor penyebab pembiayaan bermasalah, upaya untuk meminimalisasi/menekan pembiayaan bermasalah dan penyelesaian pembiayaan bermasalah pada Bank Syariah Mandiri (BSM) Kantor Cabang Kudus. Metode pendekatan yang digunakan yaitu yuridis sosiologis. Teknik pengumpulan data dengan data primer dan data sekunder. Setelah data diperoleh, disusun dan dianalisis secara sistematis. Hasil penelitian diperoleh bahwa faktor penyebab pembiayaan bermasalah pada BSM Kantor Cabang Kudus karena ekonomi makro (inflasi), kegagalan bisnis, dan internal nasabah. Upaya untuk menekan/meminimalisasi pembiayaan bermasalah dengan pendekatan analisis pembiayaan, prinsip analasis pembiayaan terdiri $5 \mathrm{C}$ dan prinsip syariah. Penyelesaian pembiayaan bermasalah dilakukan melalui penagihan, restrukturisasi, dan pengambilalihan agunan.
\end{abstract}

Kata Kunci : Penyelesaian, Pembiayaan Bermasalah, BSM Cabang Kudus 


\section{PENDAHULUAN}

Undang-Undang Nomor 25 Tahun 2004 tentang Sistem Perencanaan Pembangunan Nasional menyebutkan bahwa pembangunan nasional Indonesia adalah upaya yang dilaksanakan oleh semua komponen bangsa dalam rangka mencapai tujuan bernegara. Tujuan bernegara yang dimaksud merupakan tujuan nasional Indonesia sebagaimana tercantum dalam alenia IV pembukaan UndangUndang Dasar Negara Republik Indonesia Tahun 1945 yaitu memajukan kesejahteraan umum, mencerdaskan kehidupan bangsa, dan ikut melaksanakan ketertiban dunia yang berdasarkan kemerdekaan, perdamaian abadi dan keadilan sosial. Upaya untuk mewujudkan tujuan tersebut dilakukan pada berbagai aspek kehidupan masyarakat diantaranya pada bidang ekonomi.

Lembaga perbankan adalah lembaga keuangan yang memiliki peran strategis, karena bank yang berkaitan pembiayaan bagi usaha-usaha produktif yang dapat menyerap tenaga kerja. Di samping itu bank juga sebagai lembaga yang menampung dana dari pihak-pihak yang berlebihan dana. Indonesia merupakan sebuah negara yang menerapkan Dual Banking System yaitu terdiri dari perbankan konvensional dan perbankan syariah.

Perbankan Syariah menurut Pasal 1 angka 1 UU Perbankan Syariah adalah segala sesuatu yang menyangkut tentang Bank Syariah dan Unit Usaha Syariah (UUS), yang mencakup kelembagaan, kegiatan usaha, serta proses dalam melaksanakan kegiatan usahanya. Jadi, terdapat sistem konvensional dan sistem syariah pada perbankan di Indonesia.
Salah satu bank syariah di Indonesia adalah Bank Syariah Mandiri (yang selanjutnya disebut BSM) yang termasuk ke dalam Bank Umum Syariah (BUS) pertama milik pemerintah. Menurut UU Perbankan Syariah, Bank Umum Syariah adalah Bank Syariah yang dalam kegiatannya memberikan jasa dalam lalu lintas pembayaran. Secara struktural, BSM berasal dari Bank Susila Bakti (BSB), sebagai salah satu anak perusahaan di lingkup Bank Mandiri (ex Bank Dagang Negara/BDN), yang kemudian dikonversikan menjadi bank syariah secara penuh. ${ }^{47}$ Sebagai BUS yang pertama kali berdiri, BSM mempunyai jaringan kantor yang paling banyak di seluruh Indonesia yaitu Kantor Pusat Operasional/ Kantor Cabang sebanyak 129, Kantor Cabang Pembantu/Unit Pelayanan Syariah sebanyak 437, dan Kantor Kas sebanyak $54 .^{48}$

Kegiatan usaha BSM sebagai BUS menurut UU Perbankan Syariah diantaranya adalah menghimpun dana dalam bentuk simpanan maupun investasi berupa deposito, menyalurkan pembiayaan bagi hasil maupun berdasarkan akad lain, menyalurkan pembiayaan penyewaan barang bergerak atau tidak bergerak, pengambilalihan utang, melakukan usaha kartu debit dan/atau kartu pembiayaan, membeli, menjual atau menjamin atas risiko sendiri surat berharga pihak ketiga, membeli surat

\footnotetext{
${ }^{47}$ Muhammad Syafi'i Antonio, "Bank Syariah: dari Teori ke Praktik", Gema Insani, Jakarta, 2001, hlm. 25-26.

48 "Statistik Perbankan Syariah Agustus 2017”,http://www.ojk.go.id/id/kanal/syariah/ data-dan-statistik/statistik-perbankansyariah/Pages/Statistik-Perbankan-SyariahAgustus-2017.aspx, diakses pada 11 Juli 2017 pukul 20.04 WIB.
} 
berharga, menerima pembayaran tagihan surat berharga, melakukan penitipan, menyediakan tempat untuk menyimpan barang atau surat berharga, memindahkan uang, wali amanat, memberi fasilitas bank garansi atau letter of credit, melakukan kegiatan lain di bidang perbankan dan sosial, yang semuanya berdasarkan pada prinsip syariah dan sesuai dengan ketentuan peraturan perundangundangan.

Salah satu kegiatan BSM adalah menyalurkan pembiayaan sesuai dengan prinsip syariah. Pembiayaan menurut Pasal 1 angka 25 UndangUndang Perbankan Syariah adalah sebagai berikut :

"Pembiayaan adalah penyediaan dana atau tagihan yang dipersamakan dengan itu berupa:

a. transaksi bagi hasil dalam bentuk mudharabah dan musyarakah;

b. transaksi sewa-menyewa dalam bentuk ijarah atau sewa beli dalam bentuk ijarah muntahiya bittamlik;

c. transaksi jual beli dalam bentuk piutang murabahah, salam, dan istishna';

d. transaksi pinjam meminjam dalam bentuk piutang qardh; dan

e. transaksi sewa-menyewa jasa dalam bentuk ijarah untuk transaksi multijasa berdasarkan persetujuan atau kesepakatan antara Bank Syariah dan/atau UUS dan pihak lain yang mewajibkan pihak yang dibiayai dan/atau diberi fasilitas dana untuk mengembalikan dana tersebut setelah jangka waktu tertentu dengan imbalan ujrah, tanpa imbalan, atau bagi hasil."

Seiring perkembangan zaman, kebutuhan ekonomi semakin sulit untuk didapatkan. Hal ini mendorong semakin diminatinya pembiayaan sebagai langkah untuk mendapatkan pinjaman modal untuk keperluan usaha ataupun keperluan konsumtif tak terkecuali di Kabupaten Kudus. Pihak BSM Kantor Cabang Kudus tidak serta merta memberikan pembiayaan kepada calon nasabah debitor, tetapi bagi calon nasabah debitor harus melalui proses pengajuan pembiayaan diantaranya melengkapi identitas dan legalitas, laporan keuangan dan cashflow, agunan, dan proposal pengajuan pembiayaan. Setelah semua persyaratan terpenuhi, akan ditindaklanjuti dengan pemberian keputusan oleh pihak BSM Kantor Cabang Kudus atas pengajuan pembiayaan oleh calon nasabah debitor. ${ }^{49}$

Dalam memutuskan besarnya pembiayaan kepada nasabah besar dan nasabah terkait, diperlukan adanya kebijakan khusus yang bertujuan untuk melindungi kepentingan dan kepercayaan masyarakat serta memelihara tingkat kesehatan bank. ${ }^{50}$ Jika disetujui oleh pihak BSM Kantor Cabang Kudus maka dilanjutkan dengan akad atau perjanjian pembiayaan. $^{51}$

Berdasarkan Pasal 9 Peraturan Otoritas Jasa Keuangan (yang selanjutnya akan disebut POJK) Nomor 16/POJK.03/2014 tentang Penilaian Kualitas Aset Bank Umum Syariah

\footnotetext{
${ }^{49}$ Muchamat Malchan, "Wawancara Pra Survey", Staff Bidang Marketing Pembiayaan, 10 Juni 2017, Bank Syariah Mandiri cabang Kudus.

50 Zainul Arifin, "Dasar-Dasar Manajemen Bank Syariah", Pustaka Alvabet, Jakarta, 2006, cet. IV, hlm. 212.

${ }^{51}$ Muchamat Malchan, "Wawancara Pra Survey", Staff Bidang Marketing Pembiayaan, 10 Juni 2017, Bank Syariah Mandiri Kantor cabang Kudus.
} 
(BUS) dan Unit Usaha Syariah (UUS) bentuk kualitas pembiayaan ditetapkan menjadi lancar, dalam perhatian khusus, kurang lancar, diragukan atau macet. Kualitas pembiayaan kurang lancar, diragukan dan macet menurut penjelasan Pasal 3 ayat (2) huruf d POJK Nomor 15 /POJK.03/2017 tentang Penetapan Status dan Tindak Lanjut Pengawasan Bank Umum termasuk pembiayaan bermasalah atau disebut Non Performing Financing (yang selanjutnya disebut NPF) jika data yang disajikan dalam bentuk persentase. Sesuai dengan POJK Nomor 15 /POJK.03/2017 tentang Penetapan Status dan Tindak Lanjut Pengawasan Bank Umum Pasal 4 yang menyatakan bahwa Bank berada dalam pengawasan intensif Otoritas Jasa Keuangan (yang selanjutnya disebut OJK) apabila mempunyai NPF lebih dari 5\%. Maka Bank Syariah Mandiri mempunyai target NPF dengan batas $5 \%$ setiap bulan yang disampaikan dalam laporan bulanan maupun laporan triwulan.

Tingkat NPF BSM pada Tahun 2017 menurut laporan triwulan I-III secara berturut-turut mengalami penurunan dan berada dibawah angka 5\% yang berarti kesehatan bank baik. Lain halnya dengan salah satu kantor cabang yang terdapat di Kabupaten Kudus yaitu BSM Kantor Cabang Kudus pada triwulan I-III 2017 yang mengalami kenaikan NPF secara berturut-turut meskipun masih di bawah angka 5\%. Hal tersebut menimbulkan kerugian bagi pihak bank jika tidak ditangani dengan tepat. Penyumbang pembiayaan bermasalah paling banyak berasal dari jenis pembiayaan mikro yang menggunakan akad Murabahah.
Berdasarkan latar belakang di atas, ada beberapa permasalahan yang perlu untuk diteliti yaitu :

1. Apa saja faktor-faktor yang menyebabkan terjadinya pembiayaan bermasalah pada Bank Syariah Mandiri Kantor Cabang Kudus?

2. Apa upaya yang dilakukan Bank Syariah Mandiri Kantor Cabang Kudus untuk meminimalisasi pembiayaan bermasalah?

3. Bagaimana penyelesaian dan upaya pembiayaan bermasalah pada Bank Syariah Mandiri Kantor Cabang Kudus?

\section{METODE PENELITIAN}

Metode penelitian yang digunakan dalam penelitian ini adalah pendekatan yuridis sosiologis. Spesifikasi Penelitian ini menggunakan penilitian yang bersifat deskriptif analitis dan bersifat kualitatif.

Metode penentuan sampel dalam penelitian penyelesaian dan upaya menekan jumlah pembiayaan bermasalah (non performing financing/ npf) pada Bank Syariah Mandiri kantor cabang Kudus dengan menggunakan teknik non random sampling, yaitu dengan purposive sampling.

Untuk mendapatkan data yang akurat dalam memecahkan suatu permasalahan penelitian ini, maka diperlukan data yang bersifat primer dan data yang bersifat sekunder. 


\section{HASIL PENELITIAN DAN PEMBAHASAN}

\section{Faktor Penyebab Pembiayaan Bermasalah pada BSM Kantor Cabang Kudus}

Beberapa faktor penyebab pembiayaan bermasalah antara lain dari faktor internal bank, faktor internal nasabah, faktor eksternal, faktor kegagalan bisnis dan faktor ketidakmampuan manajemen. ${ }^{52}$ Menurut Muchamat Malchan, Indikasi dari faktor pembiayaan bermasalah di BSM Kantor Cabang Kudus pada Triwulan I-III tahun 2017 adalah sebagai berikut $:^{53}$

\section{a. Faktor Eksternal (Inflasi)}

Faktor eksternal adalah faktorfaktor yang berada di luar kekuasaan manajemen perusahaan, seperti bencana alam, peperangan, perubahan dalam kondisi perekonomian dan perdagangan, perubahan-perubahan teknologi, dan lain-lain. ${ }^{54}$ Adanya situasi ekonomi makro yaitu inflasi di Indonesia yang dimulai dari tahun 2014 akhirnya berdampak pada pembiayaan di BSM Kantor Cabang Kudus di tahun 2017 khususnya pembiayaan mikro. Inflasi menyebabkan penurunan daya beli, dalam kodisi demikian perusahaan dililit oleh biaya-biaya produksi dan pemasaran yang naik. ${ }^{55}$ Apabila inflasi

52 M. F. Hidayatullah, "Penyelesaian Pembiayaan Bermasalah di Bank Syariah", Interest, STAIN Jember Jurusan Syariah, Volume 12, Nomor 1, 2014, hlm. 70.

${ }^{53}$ Muchamat Malchan, "Wawancara Pribadi", Staff Bidang Marketing Pembiayaan, 14 Agustus 2017, Bank Syariah Mandiri Kantor Cabang Kudus.

${ }^{54}$ Faturrahman Djamil, "Penyelesaian Pembiayaan Bermasalah di Bank Syariah", Sinar Grafika, Jakarta, 2012, hlm. 73.

55 Rizal Nur Firdaus, "Pengaruh Faktor Internal dan Eksternal yang mempengaruhi Pembiayaan Bermasalah pada Bank Umum naik, artinya harga barang naik sehingga mengakibatkan beban di dunia usaha apalagi usaha mikro yang merupakan salah satu segmen pembiayaan di BSM Kantor Cabang Kudus untuk berproduksi semakin besar karena harga dari faktor produksi meningkat. Hal tersebut menyebabkan laba atau keuntungan usaha mikro menjadi menurun atau justru mengalami kerugian. Inflasi juga menyebabkan penurunan daya beli masyarakat yang berakibat pada penurunan penjualan sehingga dapat menurunkan return perusahaan. ${ }^{56} \mathrm{Hal}$ ini dapat mempengaruhi pengangsuran dana kepada bank.

\section{b. Kegagalan Bisnis}

Hal ini dapat terjadi karena adanya inflasi yang mempengaruhi usaha seperti yang telah dijelaskan di atas dan jika tidak dapat diatasi maka akan menyebabkan kegagalan bisnis yang berpengaruh pada pengangsuran dana. Inflasi selain dapat mempengaruhi pengangsuran dana secara langsung juga dapat menjadi salah satu pemicu kegagalan bisnis yang berujung pada terpengaruhinya pengangsuran dana.

\section{c. Faktor Internal Nasabah}

Kasus yang banyak ditemui adalah pihak nasabah atau debitor mempunyai tanggungan lain. Misalnya, nasabah atau debitor mempunyai usaha penjualan bahan pembuatan roti dan

Syariah di Indonesia", El-Dinar, Fakultas Ekonomi dan Bisnis Universitas Brawijaya, Volume 3, Nomor 1, 2015, hlm. 86.

${ }^{56}$ Iman Firmansyah, "Determinant Of Non Performing Loan: The Case Of Islamic Bank in Indonesia", Buletin Ekonomi Moneter dan Perbankan, Unversitas Siliwangi Tasikmalaya,Volume 17, Nomor 2, 2014, Hlm. 238. 
untuk memenuhi usahanya membutuhkan supplier. Dalam pembayaran dengan supplier secara cash ataupun dengan tempo beberapa waktu. Hal tersebut menyebabkan beban debitor untuk mengangsur dana menjadi lebih banyak dan pengangsuran dana ke BSM Kantor Cabang Kudus menjadi terhambat karena mendahulukan pembayaran dengan suplier.

2. Upaya Menekan Jumlah Pembiayaan Bermasalah pada BSM Kantor Cabang Kudus

Upaya yang dilakukan BSM Kantor Cabang Kudus untuk mnekan pembiayaan bermasalah adalah dengan mneggunakan analisis kelayakan penyaluran dana yang terdiri dari pendekatan analisis pembiayaan dan penerapan prinsip analisis pembiayaan. Kemudian, menggunakan prinsip syariah.

Analisis kelayakan penyaluran dana pada BSM Kantor Cabang Kudus adalah sebagai berikut $:^{57}$

1. Analisis pembiayaan yang dapat diterapkan oleh para pengelola bank syari'ah dalam kaitannya dengan proses pengajuan pembiayaan, yaitu:

a. Pendekatan jaminan, artinya bank dalam memberikan pembiayaan selalu memerhatikan kuantitas dan kualitas yang dimiliki oleh calon nasabah debitor.

b. Pendekatan karakter, artinya bank mencermati secara sungguh-sungguh terkait

${ }^{57}$ Muchamat Malchan, "Wawancara pribadi", Staff Bidang Marketing Pembiayaan, 14 Agustus 2017, Bank Syariah Mandiri Kantor Cabang Kudus. dengan karakter calon nasabah debitor.

c. Pendekatan kemampuan pelunasan, artinya bank menganalisis kemampuan calon nasabah debitor untuk melunasi jumlah pembiayaan yang telah diambil.

d. Pendekatan dengan studi kelayakan, artinya bank memerhatikan kelayakan usaha yang dijalankan oleh calon nasabah debitor.

e. Pendekatan fungsi-fungsi bank, artinya bank memperhatikan fungsinya sebagai lembaga intermediary keuangan, yaitu mengatur mekanisme dana yang dikumpulkan dengan dana yang disalurkan. ${ }^{58}$

2. Penerapan prinsip analisis pembiayaan. Prinsip analisis pembiayaan didasarkan pada rumus 5C, yaitu: ${ }^{59}$

a. Character, penilaian karakter ini adalah untuk mengetahui sampai sejauh mana iktikad calon nasabah debitor untuk memenuhi kewajibannya (willingness to pay) sesuai dengan perjanjian. Character sebagai bahan pertimbangan pertama pada saat pengajuan pembiayaan. BSM Kantor Cabang Kudus melakukan pengecekan secara online pada website resmi Bank Indonesia yaitu Sistem Infromasi Debitor

\footnotetext{
58 Muhammad, "Manajemen Bank Syariah", UPP AMP YKPN, Yogyakarta, 2005, hlm. 305.

${ }^{59}$ Muchamat Malchan, "Wawancara Pribadi", Staff Bidang Marketing Pembiayaan, 14 Agustus 2017, Bank Syariah Mandiri Kantor Cabang Kudus.
} 
(SID) yang sering di sebut BI checking. Selanjutnya, BSM Kantor Cabang Kudus dengan melakukan survey ke lokasi usaha dan bertanya kepada tetangga atau warga sekitar. Adapun acuannya adalah apabila calon nasabah debitor bersikap baik dan bertanggung jawab.

b. Capacity, penilaian ini dilakukan dengan laporan keuangan atau nota-nota keuangan. Survey juga dilakukan BSM Kantor Cabang Kudus ke lokasi usaha tanpa sepengetahuan calon nasabah debitor untuk mengetahui apakah usaha yang dijalankan berjalan lancar atau tidak sehingga dapat menjadi bahan pertimbangan.

c. Capital, modal diperlukan bank sebagai alat kesungguhan dan tanggung jawab nasabah dalam menjalankan usahanya karena nasabah juga ikut menanggung risiko terhadap gagalnya usaha. Informasi ini diperoleh dari wawancara langsung dengan calon nasabah debitor atau melalui legalitas usaha jika ada. Legalitas disini berarti usaha calon nasabah debitor sudah berbadan hukum dan jika suatu usaha mempunyai badan hukum maka telah ditentukan besar modal usahanya.

d. Collateral, yaitu barang yang diserahkan sebagai jaminan. Penilaian ini meliputi jenis, lokasi, bukti kepemilikan dan status hukumnya. Jaminan yang diberikan dapat berupa benda bergerak dan benda tak bergerak. Benda bergerak yang dapat dijaminkan adalah mobil dengan ketentuan bahwa mobil tersebut masih layak untuk dijadikan jaminan. Benda tak bergerak yang dapat dijadikan jaminan yaitu tanah dan/atau bangunan untuk dibebani dengan hak tanggungan.

e. Condition of economy, yaitu keadaan politik, sosial, ekonomi, budaya yang mempengaruhi keadaan perekonomian yang dapat mempengaruhi kelancaran usaha nasabah atau debitor. ${ }^{60}$ Hal ini dapat dilihat dari trend bisnis, maksudnya adalah usaha apa yang sedang berjalan dengan lancar pada saat pembiayaan diajukan.

3. Prinsip Syariah

Prinsip syariah menurut penjelasan Pasal 2 UU Perbankan Syariah adalah kegiatan yang tidak mengandung unsur:

a. riba, yaitu penambahan pendapatan secara tidak sah (batil) antara lain dalam transaksi pertukaran barang sejenis yang tidak sama kualitas, kuantitas, dan waktu penyerahan $(f a d h l)$, atau dalam transaksi pinjam-meminjam yang mempersyaratkan Nasabah Penerima Fasilitas mengembalikan dana yang diterima melebihi pokok pinjaman karena berjalannya waktu (nasi'ah);

\footnotetext{
${ }^{60}$ Veithzal Rivai dan Andria Permata Veithzal, "Credit Management Handbook: Teori, Konsep, Prosedur, dan Aplikasi Panduan Praktis Mahasiswa, Bankir, dan Nasabah", PT. Raja Gafindo Persada, Jakarta, 2006, hlm. 289-292.
} 
b. maisir, yaitu transaksi yang digantungkan kepada suatu keadaan yang tidak pasti dan bersifat untung-untungan;

c. gharar, yaitu transaksi yang objeknya tidak jelas, tidak dimiliki, tidak diketahui keberadaannya, atau tidak dapat diserahkan pada saat transaksi dilakukan kecuali diatur lain dalam syariah;

d. haram, yaitu transaksi yang objeknya dilarang dalam syariah; atau

e. zalim, yaitu transaksi yang menimbulkan ketidakadilan bagi pihak lainnya.

\section{Penyelesaian Pembiayaan Bermasalah pada BSM Kantor Cabang Kudus}

\section{a. Penagihan}

Kegiatan penagihan ini biasa disebut dengan monitoring nasabah yang dilakukan dengan cara sebagai berikut : ${ }^{61}$

1. Pada tanggal jatuh tempo, pihak bank akan menelepon nasabah debitor yang belum membayar atau saldo rekening yang dimiliki tidak cukup untuk membayar angsuran bulanan. Setelah lewat hari dari tanggal jatuh tempo, pihak bank mengingatkan nasabah debitor kembali melalui telepon. Dapat juga melakukan kunjungan ke rumah atau tempat usaha nasabah debitor. Hal ini dilakukan satu minggu sekali sampai nasabah membayar angsuran kepada bank.

\footnotetext{
${ }^{61}$ Muchamat Malchan, "Wawancara Pribadi", Staff Bidang Marketing Pembiayaan, 14 Agustus 2017, Bank Syariah Mandiri Kantor Cabang Kudus.
}

2. Lewat bulan dari tanggal jatuh tempo, pihak bank datang mengunjungi nasabah debitor dengan membawa Surat Peringatan (yang selanjutnya disebut SP) 1 dan memberi kesempatan untuk dilakukan restrukturisasi atau tidak.

3. Penagihan lanjutan, tahap ini dilakukan ketika nasabah debitor masih belum membayar setelah diberikan SP 1. SP 2 diberikan 2 minggu setelah SP 1. Berlanjut ke SP 3 apabila nasabah debitor belum membayar angsuran atau tidak dilakukan restrukturisasi. SP 3 diberikan 2 minggu setelah SP 2 . Jika setelah SP 1 atau SP 2 atau SP 3 nasabah debitor membayar angsuran maka proses penyelesaian pembiayaan berhenti.

\section{b. Restrukturisasi}

1. Penjadwalan kembali

(Rescheduling)

$$
\text { Penjadwalan kembali }
$$

(Reschedulling) yaitu perubahan jadwal pembayaran angsuran atau jangka waktu tanpa menambah sisa kewajiban pembayaran kepada pihak bank. Pelaksanaan rescheduling pada BSM Kantor Cabang Kudus dibedakan menjadi dua yaitu:

a) Perpanjangan jangka waktu pembayaran angsuran dilakukan agar nasabah atau debitor dapat memenuhi kewajiban. Perpanjangan jangka waktu tersebut merupakan kesepakatan antara pihak bank dengan nasabah atau debitor.

b) Tanpa adanya pemberian perpanjangan jangka waktu pembayaran angsuran. Jangka waktu pembiayaan tidak mengalami perubahan, tetapi 
jumlah angsuran yang tersisa dapat diangsur sesuai dengan kesepakatan antara nasabah atau debitor dengan pihak bank.

2. Persyaratan kembali

(reconditioning)

Persyaratan

kembali

(reconditioning) yaitu perubahan persyaratan pembiayaan baik hanya sebagian maupun seluruhnya. Reconditioning pada pembiayaan mikro di BSM Kantor Cabang Kudus dilakukan dengan perubahan jadwal pembayaran angsuran dan atau perubahan jumlah angsuran yang dibayarkan nasabah debitor.

\section{c. Pengambilalihan Agunan}

Pengambilalihan agunan oleh BSM Kantor Cabang Kudus dilakukan dengan 2 cara, yaitu : ${ }^{62}$

1) Penjualan secara sukarela

Nasabah debitor menjual sendiri agunan untuk melunasi tunggakan pembayaran kepada bank tanpa melalui pelelangan dengan mencari sendiri calon pembeli agunan. Hal ini dilakukan ketika nasabah debitor bersifat kooperatif untuk melunasi tunggakan pembayaran dengan menanggapi SP yang telah diberikan atau ketika retrukturisasi tidak dilakukan atau dilakukan restrukturisasi tetapi tidak berhasil. Harga agunan ditetapkan sendiri oleh nasabah debitor. Kemudian nasabah debitor datang ke BSM Kantor Cabang Kudus bersama dengan calon pembeli agunan untuk melaksanakan jual beli agunan. Hasil dari penjualan tersebut digunakan

${ }^{62}$ Muchamat Malchan, "Wawancara Pribadi”, Staff Bidang Marketing Pembiayaan, 14 Agustus 2017, Bank Syariah Mandiri Kantor Cabang Kudus. untuk pembayaran atas tunggakan, apabila ada sisa dari penjualan maka tetap menjadi hak nasabah debitor. Penjualan sukarela ini dapat dilakukan untuk semua jenis agunan yang diterima BSM Kantor Cabang Kudus segmen pembiayaan mikro.

2) Penjualan melalui mekanisme lelang

Mekanisme ini dilakukan oleh BSM Kantor Cabang Kudus melalui Kantor Pelayanan Kekayaan Negara dan Lelang (yang selanjutnya disebut KPKNL) ketika restrukturisasi tidak berhasil atau nasabah debitor tidak menanggapi SP 1, 2, dan 3 yang diberikan sehingga dinilai tidak kooperatif. Penjualan secara lelang hanya dapat dilakukan untuk agunan benda tidak bergerak yaitu tanah. Proses lelang di KPKNL yang diajukan oleh BSM Kantor Cabang Kudus adalah sebagai berikut :

a) Pra Lelang

BSM Kantor Cabang Kudus melakukan perhitungan nilai agunan, baik dilakukan sendiri maupun dengan Kantor Jasa Penilai Publik (yang selanjutnya disebut KJPP). Apabila terjadi perbedaan nilai agunan maka yang dipakai adalah KJPP rekanan BSM Kantor Cabang Kudus. Pengajuan permohonan tertulis beserta kelengkapan dokumen lelang. Dokumen lelang diantaranya adalah akad pembiayaan murabahah, sertifikat hak tanggungan, bukti kepemilikan hak, bukti rincian utang nasabah atau debitor, bukti peringatan wanprestasi kepada nasabah atau debitor yaitu SP 1 - SP 3, bukti pemberitahuan lelang kepada nasabah atau debitor. Penetapan jadwal oleh KPKNL. Pengumuman lelang oleh BSM Kantor Cabang Kudus. Pemberitahuan lelang kepada 
nasabah debitor oleh BSM Kantor Cabang Kudus.

b) Pelaksanaan Lelang

Setelah proses pra lelang selesai dilakukan semua, maka akan dilakukan proses lelang terhadap barang yang menjadi jaminan.

\section{Kesimpulan}

1. Faktor yang menyebabkan terjadinya pembiayaan bermasalah pada Bank Syariah Mandiri Kantor Cabang Kudus adalah :
a. faktor eksternal (inflasi)
b. faktor kegagalan bisnis
c. faktor internal nasabah.

2. Upaya yang dilakukan Bank Syariah Mandiri Kantor Cabang Kudus untuk menekan/ meminimalisasi pembiayaan bermasalah adalah melalui kelayakan penyaluran dana yang merupakan bagian tak terpisahkan dari prinsip kehati-hatian, yaitu :

a. pendekatan analisis pembiayaan yang terdiri dari pendekatan jaminan, pendekatan karakter, pendekatan kemampuan pelunasan, pendekatan studi kelayakan, dan pendekatan fungsi-fungsi bank.

b. Penerapan prinsip analisis pembiayaan teridiri 5C yaitu character, capacity, capital, colateral, dan condition of economy.

c. Prinsip syariah yaitu
penyediaan dilakukan tidak mengandung unsur riba, maisir, gharar, haram dan zalim.

3. Penyelesaian pembiayaan bermasalah pada BSM Kantor Cabang Kudus melalui : a. penagihan kepada nasabah debitor

b. restrukturisasi

c. pengambilalihan agunan.

\section{Saran}

1. Menganalisa keadaan ekonomi saat pengajuan pembiayaan misalnya usaha apa yang berjalan dengan lancar pada waktu pengajuan tersebut.

2. Melakukan upaya menekan pembiayaan bermasalah dengan lebih ketat pada analisis pembiayaan tepatnya prinsip 5C yaitu lebih mendalami karakter nasabah dan kemampuan manajemen usaha nasabah.

3. Penyesuaian penyelesaian pembiayaan bermasalah dengan peraturan yang berlaku.

\section{DAFTAR PUSTAKA}

Muhammad, 2005, "Manajemen Bank Syariah", Yogyakarta, UPP AMP YKPN.

Muhammad Syafi'i Antonio, 2001, "Bank Syariah: dari Teori ke Praktik”, Jakarta, Gema Insani.

Veithzal Rivai dan Andria Permata Veithzal, 2006, "Credit Management Handbook: Teori, Konsep, Prosedur, dan Aplikasi Panduan Praktis Mahasiswa, Bankir, dan Nasabah", Jakarta, PT. Raja Gafindo Persada. 
Zainul Arifin, 2006, “Dasar-Dasar Manajemen Bank Syariah", Jakarta,Pustaka Alvabet, cet. IV.

M.F. Hidayatullah, 2014, "Penyelesaian Pembiayaan Bermasalah Di Bank Syariah”, Interest, STAIN Jember Jurusan Syariah, Volume 12, Nomor 1.

http://www.ojk.go.id/id/, diakses pada 11 November 2017 pukul 20.04 WIB. 